\title{
Open Educational Resources Development on Higher Education in a Collaborative Process of Co-Creation
}

\author{
Patrícia Lupion Torres, Danielle Cristine Boaron, Raquel Pasternak Glitz Kowalski \\ Pontifícia Universidade Católica do Paraná, Curitiba, Brazil \\ Email: patricia.lupion@pucpr.br
}

How to cite this paper: Torres, P. L., Boaron, D. C., \& Kowalski, R. P. G. (2017). Open Educational Resources Development on Higher Education in a Collaborative Process of Co-Creation. Creative Education, 8, 813-828.

https://doi.org/10.4236/ce.2017.86059

Received: March 16, 2017

Accepted: May 14, 2017

Published: May 17, 2017

Copyright ( 92017 by authors and Scientific Research Publishing Inc. This work is licensed under the Creative Commons Attribution International License (CC BY 4.0).

http://creativecommons.org/licenses/by/4.0/

\begin{abstract}
This paper aims to expose the results of a qualitative research process based by participatory research methodology, developed within a research of Theory and Pedagogical Practice in the Instruction of Professors, from the StrictoSensu Post-Graduate Program in Education (PPGE) at Pontificia Universidade Catolica do Parana (PUCPR), Curitiba, Brazil, as part of the activities of the research group Pedagogical Practice on Teaching and Learning with Educational Technologies (PRAPETEC) research group. From 2013 to 2016, several actions were developed by the research group to contribute to research on collaborative learning, co-creation, open education and open educational resources, due to a partnership with the Collaborative Open Learning Community (coLearn) under the coordination of Dr. Alexandra Okada. In this context, the question to this investigation was as follows: how can open educational resources (OER) development on Higher Education in a collaborative process of co-creation contribute to student learning? The aim of this study was to promote a collaborative and open educational experience for students through the creation of OER as well as the incorporation of Facebook, YouTube and Whats App as supporting environments in the teaching and learning process. Based on the analysis of the obtained results, it was observed that this experience was positive for contributing to the knowledge production in a collaborative way, with criticality, autonomy and creativity. And also, the students experienced an innovative methodology, allowing those who already act as professors to reflect on their pedagogical practice.
\end{abstract}

\section{Keywords}

Collaborative Learning, Co-Creation, Open Educational Resources, Open Education 


\section{Introduction}

The democratization of internet use enabled the easy access to a huge number of resources and the creation of new information at the speed of a click. In this new context of openness, sharing, collaboration, interactivity and content production are keywords. In this sense, professors cannot disregard these changes and must find new learning methodologies in order to promote knowledge construction in a collaborative, critical and creative way, resulting in a meaningful apprenticeship process.

Since late $20^{\text {th }}$ century until nowadays, the need of changes in society in order to embrace new principles, which facilitates an overall view, connection, net and collaboration has been debated. Teaching laid on memorization and repetition process, underpinned by Newtonian-Cartesian thinking, does not fit the way students are used to access and process information. The classic class "chalk and talk" (Veen \& Vrakking, 2009: 47) is contrasting with their life beyond the walls of the institution (they have control of their activities; there is social network immersion; They produce and manage new knowledge because "they feel forced to be passive and listen to a teacher who explains" (Veen \& Vrakking, 2009: 47). In this context, "the emphasis of the pedagogical process is on product, on result, on content memorization, restricting in meet tasks that often, don't make sense or significance for those who perform them" (Behrens, 2011: 23). Therefore, the need of developing new educational models arises in order to overcome the fragmented and traditional vision of teaching, putting the student as the active subject of his knowledge construction.

In this process, professors stop being the only ones who hold knowledge and take over the role of a partner, helping students to become independent, questioner, critic and reflective. Besides, encouraging and motivating them to transform information into meaningful knowledge.

In this context, it is worth mentioning the Ferguson (1992: 276) contribution stating that:

The old assumptions generate questions about how to achieve norms, obedience, and correct answers. The new assumptions lead to questions about how to motivate for lifelong learning, how to strengthen self-discipline, how to awaken curiosity, and how to encourage creative risk in people of all ages.

The vision of the whole proposed by the new paradigm instigates professors to rethink their pedagogical practice, aiming precisely to involve the student as a subject of his knowledge construction, making it autonomous, critical and reflective.

According to Capra (1997: 25), "the new paradigm may be called a holistic worldview, seeing the world as an integrated whole rather than a dissociated collection of parts". In the same way, to Behrens (2006: 19) "the innovative paradigms are strongly focused on the vision of the whole, interconnection, interrelationship, overcoming the fragmented vision of the universe and the search 
for the rapprochement of the parts to reconstitute the whole in the various areas of knowledge".

Thus, Morin (2005: 38) proposed the concept of complexity, which originates from the term "complexus", that:

[...] means that which is woven together. In fact there is complexity whenever the various elements (economic, political, sociological, psychological, emotional, mythological...) that compose a whole are inseparable, and there is inter-retroactive, interactive, interdependent tissue between the subject of knowledge and its context, the parts and the whole, the whole and the parts, the parts amongst themselves. Complexity is therefore the bond between unity and multiplicity.

According to Behrens (2014: 213), the pursuit of the vision of the whole in education, according to a complex approach, implies overcoming reproduction to knowledge produce,

aiming at the formation of cognitive and critical subjects, and this path implies valuing reflection, discussion, action, curiosity, uncertainty, provisionality, questioning and, therefore, the formation of students depends on the reconstruction of educational practice.

Therefore, one of century challenges for professors is overcoming conservative methods and achieving the paradigm of complexity, to train more independent, responsible, critic and reflective professionals, through collaboration, co-creation, content production and interactivity.

This article will be presented in six subdivisions, starting with the concepts of Collaborative Learning, Open Education and Open Educational Resource. The survey data are presented in ward 5 , followed by the search consideration. To conclude, the conclusion of the article is presented.

\section{Collaborative Learning}

Collaborative learning arises in the academic universe as a possibility of overcoming traditional teaching. This methodology decentralizes the figure of the professor as a knowledge transmitter, and he take over the role of a partner with their students, without hierarchies, in a horizontal relationship. In this process, students being the active subject, responsible, critic and reflective and learning is built on a collaborative, participatory and interactive process in which all involved work with freedom, autonomy and responsibility, motivated by the achievement of a common goal.

Dillenbourg (1999: 1) broadly defines this learning model as "[...] a situation in which two or more people learn or attempt to learn something together". He explains that "two or more" may be a pair, a small group with three to five people, a class with twenty to third students, a community of a few hundreds or thousands of people or a society with several thousands or millions of subjects. 'Learn something' refers to follow a course, study course material, learn from li- 
felong work practice, among others. Finally, "together" means the different forms of social interaction, like face-to-face, computer mediated (synchronous or asynchronous), a truly joint effort or whether the labor is divided in a systematic way (Dillenbourg, 1999).

Collaborative learning is a reacculturation process that helps students integrate into new knowledge communities, with different characteristics from which they already belong (Torres, Alcântara, \& Irala, 2004: 134).

According to Roberts (2005), collaborative learning sometimes can be confused as a way of assisting only the less capable students. However, "[...] the best way to learn a subject is to teach it, and for good reason-when teaching, one needs to gain a thorough knowledge of the subject, not only to prepare material, but also to be able to answer questions confidently" (Roberts, 2005: 7).

Roberts (2005) lists in three categories some benefits of adopting collaborative learning: academic, social and psychological benefits. Academically, this model of learning promotes critical thinking skills; involves students actively in the learning process; improves classroom results; and promotes the development of problem solving techniques. Socially, develops a social support system for students; builds diversity understanding among students and staff; and establishes a positive atmosphere for modeling and practicing cooperation. Finally, psychologically, can increase students' self-esteem; and develops positive attitudes towards professors.

Besides that, Al-Rahmi, Othman, Musa (2014: 2014) highlights that: “[...] collaborative learning using the social media such as Facebook, E-mail, twitter etc. facilitates learning and knowledge sharing among students, teachers or trainers to the context in real life situation and experiences".

According to Torres (2004: 69), the pedagogical principles that fulfill a collaborative learning methodology are:

a) Active student participation in the learning process;

b) Learning mediation by professors and tutors;

c) Collective knowledge production, which emerges from the exchange among peers, the students' practical activities, their reflections, their debates and questions;

d) Interactivity among the various actors involved in the process;

e) Expression and communication processes stimulation;

f) Flexibility of roles in the process of communications and relations in order to allow the collective knowledge production;

g) Planning, development and evaluation of activities systematization;

h) Diversities and differences among students' acceptance;

i) Learner autonomy development in the learning process;

j) Freedom with responsibility appreciation;

k) Commitment to authorship;

l) Focuses on the process, not the product.

Based on these principles, group collaboration can produce better results for students than individually, because, in accordance with Pallof \& Pratt (2002: 
141) "when students work together, i.e., collaboratively, they produce deeper knowledge, at the same time they cease to be independent and become interdependent". For this reason, "the group is, therefore, above all a tool, an instrument at the service of the collective knowledge construction" (Torres, 2004: 103).

Besides that, "collaborative learning brings an important contribution of school to formation of committed people to the development of a humane, just and solidary society" (Torres, 2007: 93).

In this context, it is perceived that collaborative learning is an appropriate methodology to meet the new demands of society, to enable the collective construction of meaningful knowledge through interaction, solve complex problems with creativity and criticality, exchange experiences, transforming learning in a social activity. For this purpose, according to Behrens (2006: 76):

Restructure the methodology offered within the classroom demands contemplating activities that overcome the walls of the classrooms, laboratories and university. Challenging activities to respond to existing problems require the creation of virtual and face-to-face spaces inside and outside the university.

Based on the contributions of the aforementioned authors, it is understood that collaborative learning makes it possible to overcome a traditional view of teaching, favoring the formation of students more independent, responsible for personal and collective learning, critical, creative and more committed to society surrounding. However, the simple fact of using technological resources without changing the configuration of teaching classes and practices will not provide a propitious space for the construction of collaborative and meaningful learning.

\section{Open Education}

The open education movement represents an opportunity for information and resources to be freely shared, as well as for the learning and teaching process to become more open, collaborative, participatory, flexible and interactive, in order to everyone involved can participate with freedom, autonomy and responsibility.

In general, the term 'open education' has been currently reduced to the use of open educational resources (OER). However, according to Santos (2012: 72), "there is a consensus on academy that there is no single definition of open education". It is a concept that over the centuries has been used to represent different educational movements and, therefore, refers to several aspects of openness, such as: access to content, the platform used, access without geographical or financial barriers, among others. However, pedagogical practices that encourage freedom and autonomy for the student to decide where, how and what to study, according to their lifestyle and rhythm, are characteristics that configure this educational model (Santos, 2012).

Based on Moraes's (2008: 16) statement that "a globalized world is a networked world", it is understood that in the current context of openness, espe- 
cially the use of social networks, when using, producing, publishing and sharing information in digital media, various users can connect, form a large net, interact and engage to collaboratively achieve a goal of common interest. In this process, knowledge is built openly and meaningfully.

According to Palloff \& Pratt (2015: 22): "students are increasingly demanding the inclusion of technology into courses, and teachers need to respond". In this way, Moreira \& Januário (2014: 74) believe that “[...] being social networks collective and collaborative spaces of communication and information exchange, can facilitate the creation and development of communities of practice or learning as long as there is an explicit educational intentionality."

In this perspective, Fong (2014: 406) complements that:

Cognitive science and learning theory also tell us that learning occurs the most effectively when the learner is most engaged to learn, such as seeking an answer to a question. When this happens, at the moment students' curiosity is piqued and can be satisfied, learning takes place.

Thus, in an open environment, students are free to express their opinions and ideas without hierarchies, to investigate, collaborate, co-create, progress and achieve learning in accordance with their interest and rhythm. Therefore, being engaged and involved, he will commit himself to the teaching-learning process with dedication and autonomy.

For Boaron \& Torres (2016: 17):

Through open education, students are given autonomy to work on their own knowledge construction and the professor, as mediator and partner of the teaching and learning process, monitors the development and progress of the student, valuing the process and not the product, encouraging him to follow in front. In addition, because they are open spaces, the whole process is visible to other students, so that everyone can collaborate in the creation of contents, talking, working together, exposing ideas, altering, improving and sharing, being essential the learning of the group focusing on the meaningful knowledge production.

Exploring the potential of the internet and especially of open spaces such as social networks, Universities are challenged to reflect on the pedagogical practice that has been developed over the years. They need to evolute to transform the traditional methodology offered in the classroom, looking for open activities that overcome the walls of the institution, providing a space for exchanging experiences, encouraging autonomy, reflection and critical thinking.

\section{Open Educational Resources}

The term "open educational resources" (OER) was created in 2002 at the UNESCO Forum on the Impact of Open Course Ware for Higher Education in Developing Countries to refer to the "[...] teaching, learning and research resources that reside in the public domain or have been released under an intel- 
lectual property license that permits their free use or re-purposing by others" (Santos, 2013: 21).

Complementing this definition, Hylén (2006) clarifies that OER can be: learning contents (full courses, content modules, learning objects, among others); Tools (software to support the development, use, reuse and distribution of learning content, tools and systems for searching, organizing, managing and developing content as well as online learning communities) and implementation resources (intellectual property licenses to promote open publication of materials, design principles of best practice, among others).

Considering a huge number of open resources available for use on the internet, OER term emerged, according to Okada (2011: 122), “[...] to highlight the production of open content for learning purposes". In this sense, Butcher (2011: 34) points out that "[...] the key differentiator between an OER and any other educational resource is its license".

OER can be licensed through one of six available Creative Commons (CC) licenses (Figure 1), which indicate the possibilities or restrictions to the user, without the need to request permission from the author. When you license a material, you can choose one of the licenses, from the most restrictive to the most permissive, according to your need.

Being an OER a licensed educational material that allows reuse, sharing and review by any user, without bureaucratic impediments, Butcher (2011: 13) highlights the educational potential of these materials through three topics. First, OER can reduce the cost of accessing resources, because removes the need to pay royalties, as well as facilitate the use without having to ask the creator's permission, as copyrighted material. In this way, there will increased availability of high quality, relevant learning materials. The second topic emphasizes students as active participants in educational processes. By facilitating the reuse and adaptation of resources, content licenses encourage students to contribute significantly to creation more effective learning environments. Finally, the last topic highlights the potential to build educational materials and the realization of the necessary instructional design to creation of high quality materials.

For Briceño (2014), OER are increasingly viewed as an economic, accessible and democratic opportunity to access information, knowledge and learning. According to the author, behind the philosophy of OER is the notion that knowledge is a public good and, through shared content - by professors, students and

\section{cc)creative}

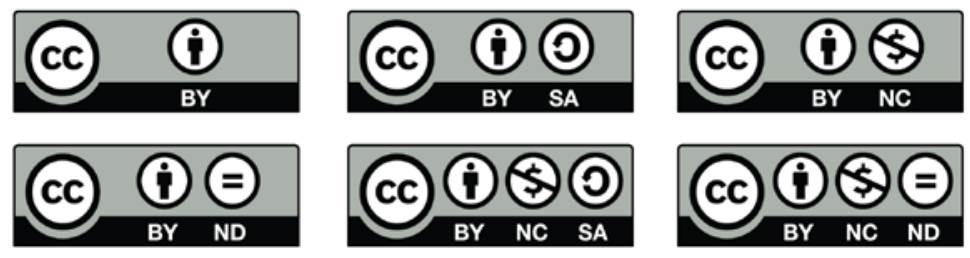

Figure 1. Creative commons licenses. 
users-it can make formal and informal education less entry barriers and be more inclusive.

Given the potential of OER, it is understood that the insertion and use will provide benefits and gains for professors and students of higher education. However, according to Santos (2013: 22) the OER movement didn't have much evolution and still has a long way to go in Brazil. Ehlers (2011) explains that this occurs because, for him, there is an emphasis on expanding access to digital content, without considering whether this will support educational practices, promoting quality and innovation in teaching and learning process.

\section{Research}

This research was conducted from 2013 to 2016 in Pontificia Universidade Catolica do Parana (PUCPR), as part of the activities of the research group Pedagogical Practice on Teaching and Learning with Educational Technologies (PRAPETEC), from the Stricto Sensu Post-Graduate Program in Education (PPGE), within a research of Theory and Pedagogical Practice in the Instruction of Professors.

The activities that will be presented were developed by the research group to continue research on open education, open educational resources, collaboration and co-creation. The beginning of research about OER in the PRAPETEC research group was a Collaborative Open Learning Community (coLearn) project coordinated by Dr. Alexandra Okada, named The Open Scout Project-Tool Library, Open Educational Resources and Social Network: Colearning and Professional Development (http://oer.kmi.open.ac.uk). This project involved several Brazilian and European universities for the construction of OER and was the origin of the discussion and production of OER in the PRAPETEC research group.

In the continuity of the discussions and for new OER development, complementary to the first OER developed in the coLearn project and published in the Tool Library of the Open University, PRAPETEC research group met biweekly during the years 2013 and 2014.

At these meetings, from 2014, the activities for production of OER were organized. First, the visual identity was created that would be used in all OER developed. Because it was a collaborative work, all students were identified in OER and the name of each author responsible for the material was highlighted with a different color from the others (Figure 2).

At that time, each student was responsible for producing an OER on a theme chosen as his responsibility. These OER were shared and reviewed by all peers in a collaborative co-creation process. After all revisions, OER were published on Slide Share platform with a CC license (Figure 3).

Students also carried out the bibliographic research activities of the themes listed by each one and discussed with the group coordinator. In addition to the contents that would make up OER, those involved also searched for images, music, poetry, concept maps, software and other open resources that could contribute to the production of the material. 


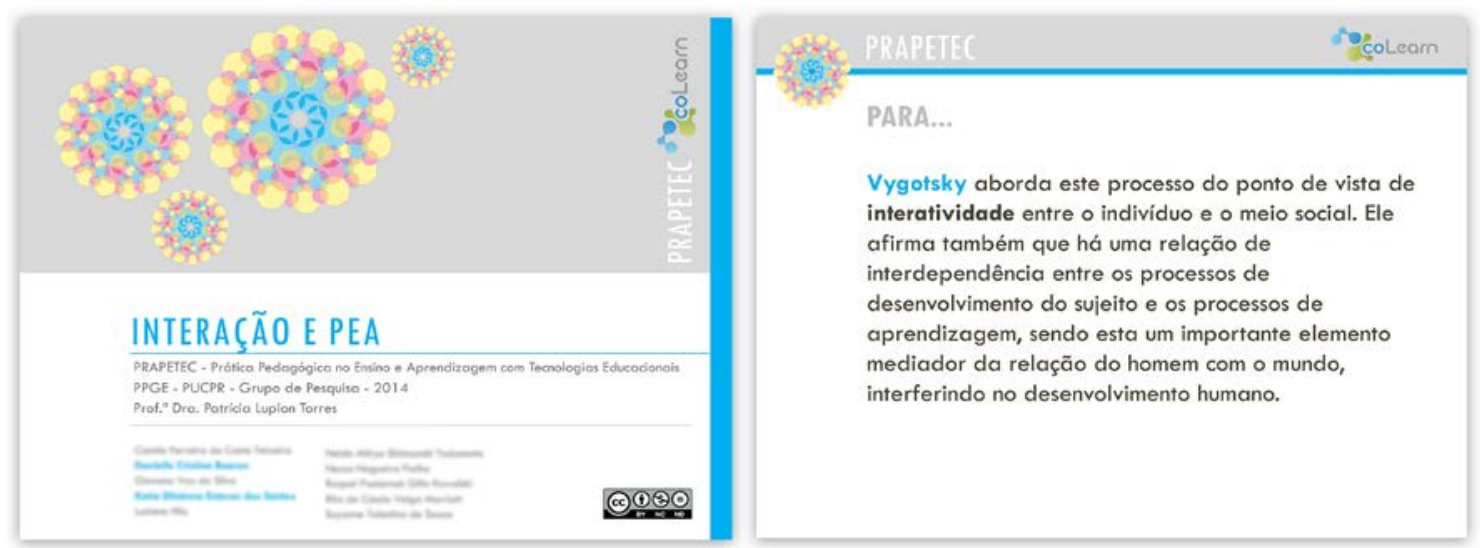

Figure 2. PRAPETEC's research group visual identity.

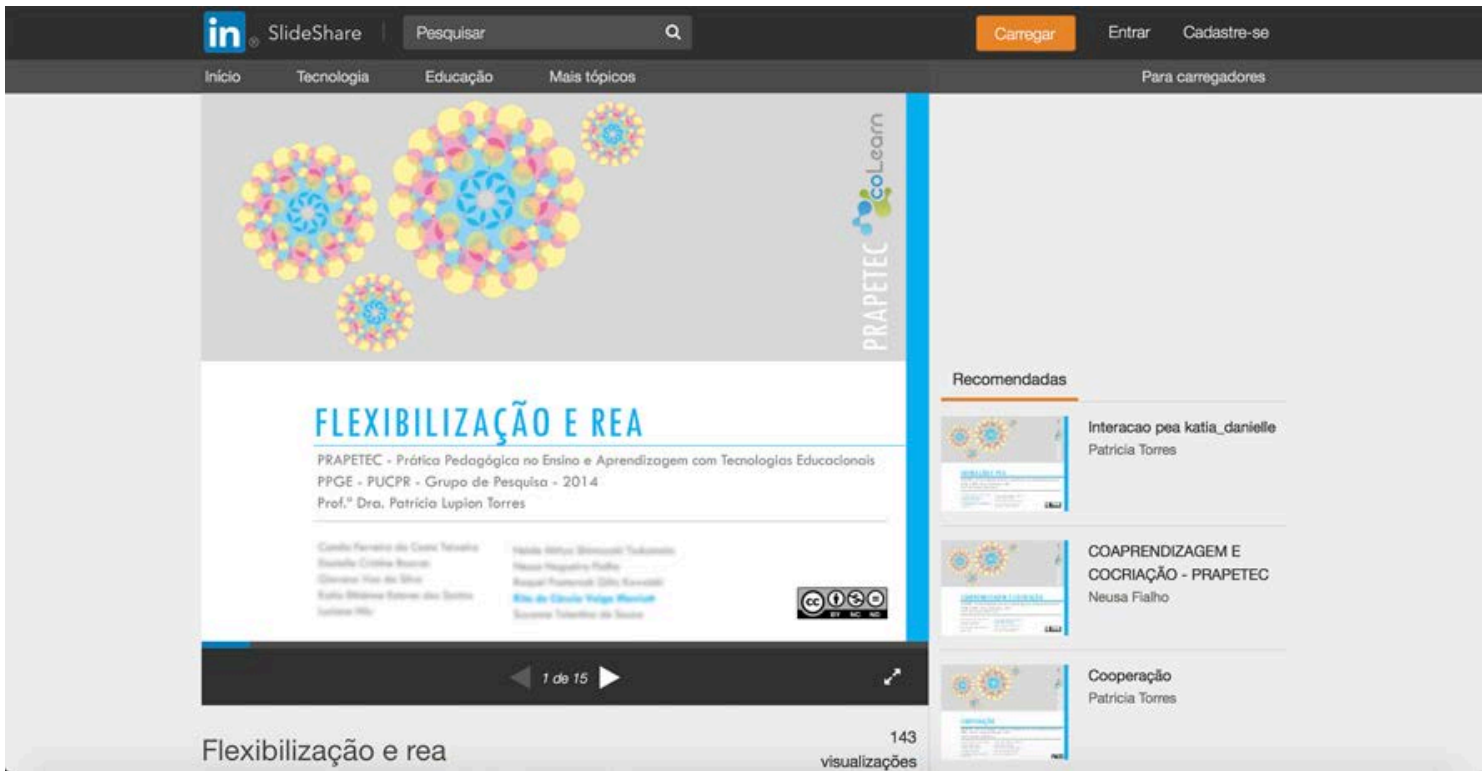

Figure 3. OER published in Slide Share.

In this research focus, in 2015 PRAPETEC research group developed several activities on themes proposed by European partners the ENGAGE Project (www.engagingscience.eu/en/overview), which instigated discussion and reflection on socio-scientific issues that impact the planet, such as agrobiodiversity and GM products, through OER. In this project, PRAPETEC research group created collaboratively different types of OER, such as: videos, games, illustrations, photographs, podcasts and slide shows. Figure 4 and Figure 5 are examples of OER developed.

In 2015 and 2016, other group actions aimed at the co-investigation by means of sharing by the social network site Facebook of materials searched on the internet OER developed. In order to continue the discussions and production of OER, PRAPETEC research group met bi-weekly. At these meetings, researchers and students of the master's and doctoral program, as well as faculty members and PIBIC fellows, participated in the research group discussing theoretical references that subsidized the production of texts. A collaborative production pro- 

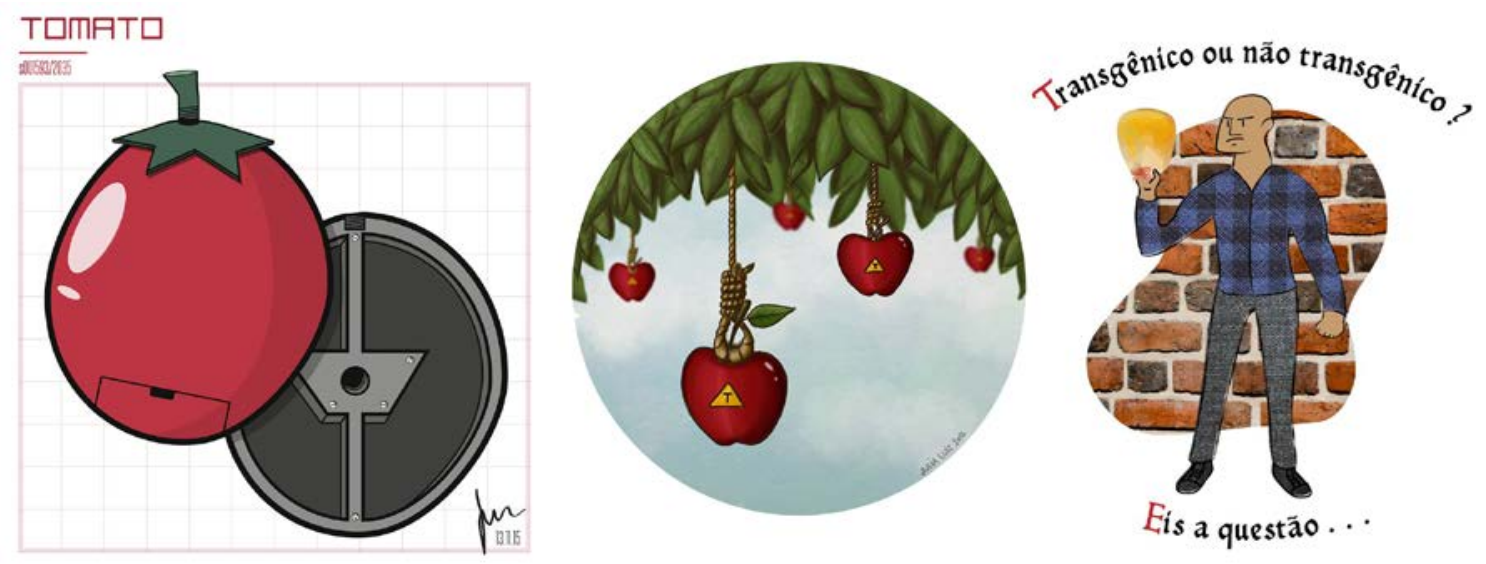

Figure 4. GM Food illustrations.
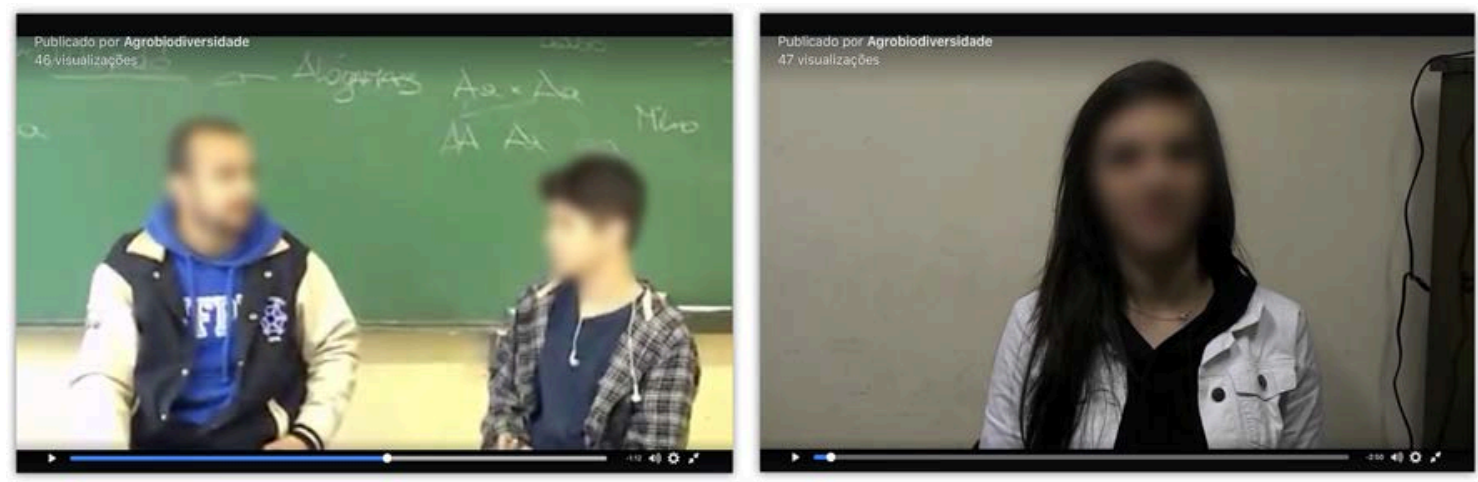

Figure 5. Videos.

posal for an open journal was also developed. Theoretical references read and discussed subsidized the first moment of topics definition that would be addressed in the journal, as well as the production of the collaborative texts that composed the journal.

In Facebook group were published all the necessary guidelines for the development of activities carried out at a distance, as well as the organization of the tasks developed in person at the meetings of the group. Examples of postings on meeting dates and group activities are shown in Figure 6.

All activities proposed by researchers were presented and discussed at the beginning of each semester of 2015 and 2016. At each meeting, and also in the intervals between them, students were responsible for researching and proposing new content complementary to the ones listed first. Such content was shared on Facebook and Whats App and generally featured in the YouTube video format, OER links and texts available on internet. Pedagogical mediation for OER journal construction took place through the communication tools of Facebook and Whats App. Examples of these interactions can be seen in Figure 7.

It was also organized with the students the production of videos with key ideas of the proposal, which along with all OER developed, were presented to the peers in the group's face-to-face meeting at the end of the semester. This activities cycle concludes with the publication of the journal on PRAPETEC research 


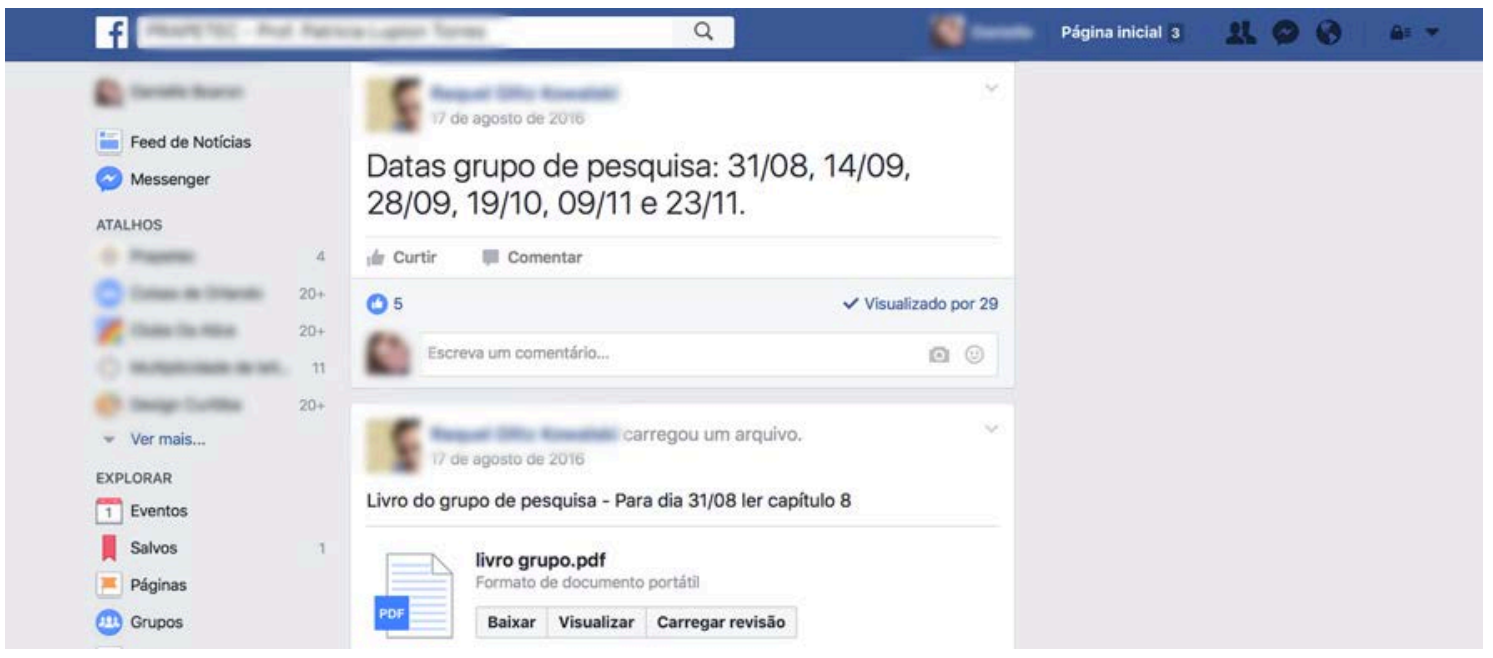

Figure 6. Schedule of meetings and activities.
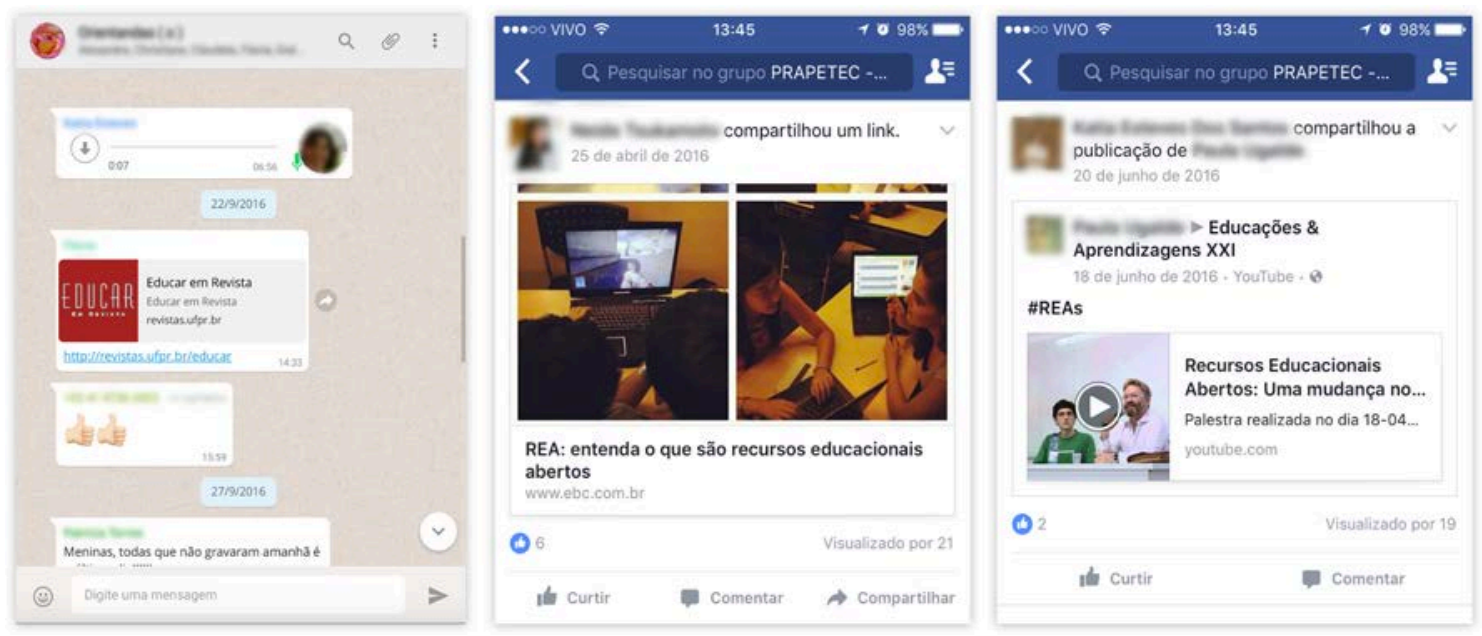

Figure 7. Examples of content shared on Whats App and Facebook.

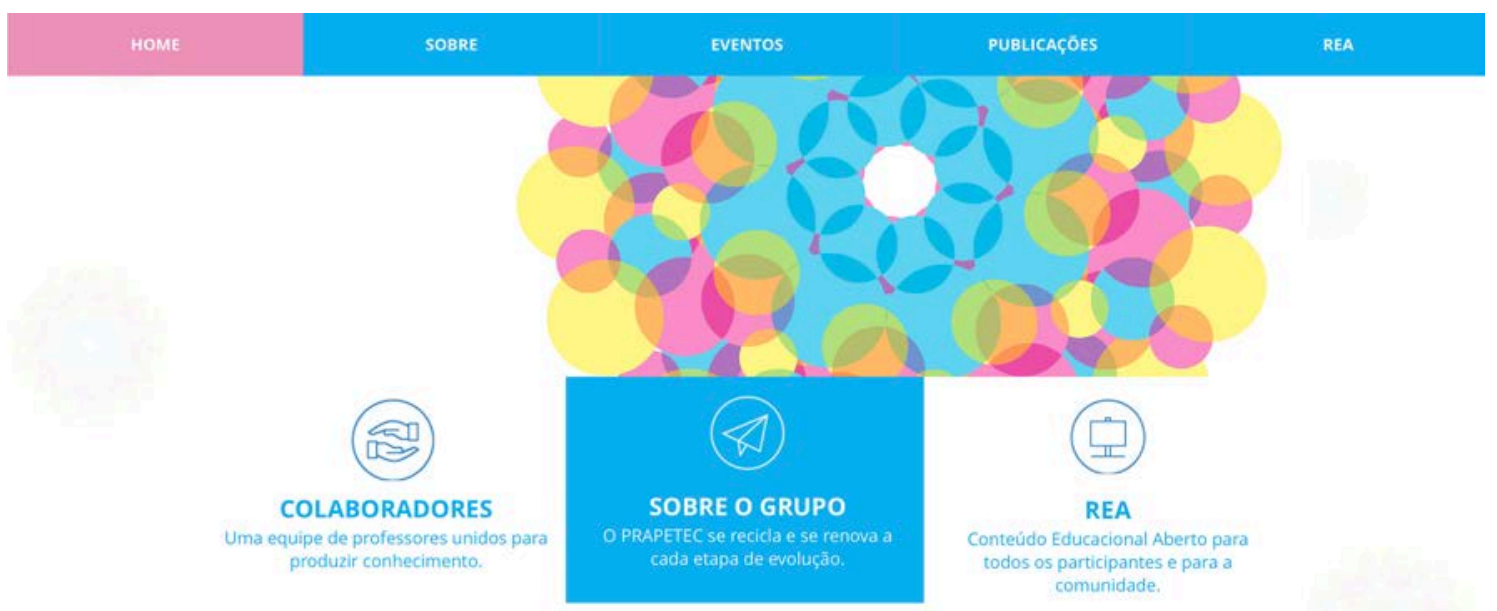

Figure 8. PRAPETEC's home page.

group website (Figure 8), where some OER developed are also available and evaluated by students and professors participating in the group. 


\section{Some Considerations about Research}

The research adopts a qualitative approach, based by participatory research methodology. For data collection, at the end of the research group's meeting cycle a questionnaire with ten open questions and was sent to fifteen participants, who volunteered. The questions were created considering the learning context and all participants answered the questionnaire. Survey questions were aimed at verifying from the student's point of view the evaluation of their learning with the production of OER, as well as the incorporation of social networks site Facebook as learning environments. Qualitative evaluation also considered the students' experience as producers of OER; complementary data posted on Facebook and observations, to deepen the interpretation and data analysis.

The participants were from undergraduate students to professors, all live in Curitiba - Brazil and all education researchers.

All participants by research group reported that they didn't encounter difficulties with basic computer skills. Some have stated that the pedagogical use of Facebook and YouTube was not a major challenge. Most had already used smartphones to access the Internet for personal and professional interests. It was also verified that the group is very homogeneous with respect to the use of educational technologies. Some participants excelled in the use of technological tools, and contributed a lot to peer learning in a process of peer tutoring.

When asked how their experience with social networking activities was and using OER, the participants emphasized that the possibility of carrying out collaborative peer-to-peer exchanges and the theoretical deepening on the themes with the support of several OER were relevant to the process of knowledge acquisition.

"It was a totally different experience because before that, I had never looked at social networks (in this case Facebook) as an environment for construction and exchanging knowledge. I really enjoyed learning in this space, because it was something dynamic, quite open to discussions and material exchange. This proposal was innovative in the sense that everyone could interfere and together create rich knowledge". Participant 4.

"Basically, I'm starting my experience with activities using OER, but even as a beginner, I realize that it is one of the most significant educational proposals in the conduct of the teaching-learning process". Participant 1.

"In a hectic everyday life, work, family and study, experiences with the use of different technologies and networks has made it possible to access varied information, contact with people from other countries that are linked to my areas of interest and especially the need to adapt the individual learning model that 'I learned in school'. As a professor, the experience also allowed me to innovate in my classes". Participant 10.

"I loved it. It was a unique opportunity to engage in collaborative peer-topeer Facebook exchanges and to gain insight into learning”. Participant 13.

When questioned about their experience with the use of OER, the participants 
responded in the most varied ways, which indicates their different knowledge levels on the subject, ranging from little theoretical knowledge and no practice until a good theoretical knowledge with some practices already experienced.

"As a first activity, I felt quite difficult, regarding the 'task' proposed on Facebook. The obstacles were caused by the difficulty in understanding what was to be done and where were located the resources that should be used. When talking about YouTube videos and other public domain resources, my familiarity is good, and I even use them for my teaching activities. As far as the traditional class is concerned, I am realizing how this paradigm break occurs in a very practical way. Collaborative learning and OER have already provided me with an innovative proposal". Participant 7.

"I have had different experiences with networking activities both as a professor of the process and others as part of groups in instruction processes. I believe that when I was part of the instruction process we were still a little immature about the use of social media and did not take full advantage of the potential offered. It innovated a lot because the networks were no longer just for social contacts and were used for distribution of information that could contribute to the process". Participant 6 .

When asked about their gains with this experience of using OER, students emphasized that they considered as a gain the collective and collaborative knowledge construction, interaction and the possibilities of developing works and researches.

"Collaborative learning, based on the constant exchange of information". Participant 8.

"Autonomy; information; relationship; respect for the production of the 'other'; respect for collectivity; motivation; dedication; deepening". Participant 10.

"Increased motivation to create and share new open resources. Opportunity to share and also utilize resources already available on the net". Participant 4.

"I believe that learning from the group was the best gain. Exchange between peers and the possibility of producing, using, remixing and reusing the remix made learning more meaningful". Participant 13.

When questioned if they believed that the use of OER promotes an improvement in the teaching and learning process, all the respondents were unanimous in affirming that yes, as it is observed in the following placements. They often emphasized the quality and quantity of materials available and the possibility of creatively adapting the resources to their reality and need.

"Certainly! [...] The use of OER promotes greater reach to content and information available anywhere in the world, which does not limit research in a restricted universe". Participant 7.

"By using OER in face-to-face education, I believe in improving the teach- 
ing-learning process because, in addition to developing collaborative learning, we are bringing instruments such as links, videos, chats and more. Which are the language of this new generation". Participant 8.

"The use of technological resources promotes, when used intentionally, with well-defined objectives and with meaning, gains in different aspects: in the interaction, in the amplitude of information, in the opportunities of learning, in the exchanges, in the motivation, independent of the modality to be face-to-face or distance learning". Participant 10.

"I absolutely believe that yes, because sharing and access to knowledge propels, giving a sense of universalizing knowledge". Participant 2.

"I believe, because the use of OER provides use, adaptation, remixing of didactic resources, as well as exchange of experiences that can favor and improve pedagogical practices". Participant 3.

\section{Conclusion}

Based on the obtained results, it was possible to perceive that the production of OER in a collaborative process of co-creation contributed positively to student learning. Through collective and collaborative production of resources and the interaction facilitated by social networks sites, students became active subjects in the process, constructing their own meaningful knowledge with autonomy, criticality and creativity.

Because they were active participants in this proposal, students were able to experience a methodology based on complexity paradigm, perceiving in practice the difference between the traditional teaching model and the innovator. In addition, those who already act as professors can reflect on their own pedagogical practice and are encouraged to find new ways to develop more collaborative and open methodologies with their students.

Through the sharing of the OER created, in social networks and in PRAPETEC's website, it was possible to disseminate the information beyond the members of the group and the walls of the institution.

\section{References}

Behrens, M. A. (2006). Paradigm of Complexity: Project Methodology, Didactic Contracts and Portfolios. Petrópolis: Vozes.

Behrens, M. A. (2011). The Emergent Paradigm and the Pedagogical Practice (5th ed.). Petrópolis: Vozes.

Behrens, M. A. (2014). Transformative Education: Meetings and Convergences of the Works of Paulo Freire and Edgar Morin. In R. Barros, \& D. Chotti (Eds.), Paving the Way for a Transformative Education. Lisbon: Chiado Editora.

Boaron, D. C., \& Torres, P. L. (2016). Open Educational Practice in Higher Education: An Experience with Digital Design Students. Master's Thesis, Curitiba: Pontifical Catholic University of Paraná.

Http://www.biblioteca.pucpr.br/pergamum/biblioteca/img.php?arquivo=/00005a/0000 5ae6.pdf

Briceño, M. C. C. (2014). Improving the Quality of Distance Education through the Use 
of Open Educational Resources. In F. R. Prado, \& C. Rama (Eds.), Learning Resources in Distance Education: New Scenarios, Experiences and Trends (pp. 60-67). UAP: Lima.

Http://www.universidadfutura.org/wp-content/uploads/2014/07/Recursos-del-Aprendi zaje.pdf\#page $=68$

Butcher, N. (2011). A Basic Guide to Open Educational Resources. British Columbia/Paris: COL and UNESCO.

http://unesdoc.unesco.org/images/0021/002158/215804e.pdf

Capra, F. (1997). The Web of Life: A New Scientific Understanding of Living Systems (2nd ed.). São Paulo: Cultrix.

Dillenbourg, P. (1999). What Do You Mean by Collaborative Learning? Collaborative-Learning: Cognitive and Computational Approaches. Oxford: Elsevier.

Ehlers, U. (2011). From Open Educational Resources to Open Educational Practices (p. 23). ELearning Papers.

Http://www.openeducationeuropa.eu/en/article/From-Open-Educational-Resources-to -Open-Educational-Practices

Ferguson, M. (1992). Ch. 5: Fly and See: New Pathways to Learning. In The Aquarian Conspiracy (pp. 264-305). Rio de Janeiro: Record.

Fong, B. C. (2014). Open for What? A Case Study of Transformation and Institutional Leadership. In T. Iiyoshi, \& M. S. V. Kumar (Eds.), Open Education: The Collective Advancement of Education through Technology, Content and Open Knowledge. São Paulo: Abed.

Hylén, J. (2006). Open Educational Resources: Opportunities and Challenges. Paris: OECD's Center for Educational Research and Innovation.

Http://www.oecd.org/edu/ceri/37351085.pdf

Moraes, M. C. (2008). Ecology of Knowledge: Complexity, Transdisciplinary and Education. São Paulo: Antakarana/WHH-Willis HarmanHouse.

Moreira, J. A., \& Januário, S. (2014). Social Networking and Education Reflections about Facebook as a Learning Space. In C. Porto, \& E. Santos (Eds.), Facebook and Education: Publish, Enjoy, Share (pp. 67-84). Campina Grande: EDUEPB.

Morin, E. (2005). The Seven Knowledges Necessary for the Education of the Future (10th ed.). Creative Commons License.

Okada, A. (2011). COLEARN 2.0: Reflecting on the Concept of Co-Learning via OER in Web 2.0. In D. M. V. Barros, C. Neves, F. B. de Seabra, J. A. M. Moreira, \& S. Henriques (Eds.), Education and Technologies: Reflection, Innovation and Practices. Lisboa: Free Digital Publication. http://pt.scribd.com/doc/53937491/e-Book-Completo-FINAL

Palloff, R. M., \& Pratt, K. (2002). Building Cyberspace Learning Communities: Effective Strategic for the Online Classroom. Porto Alegre: Artmed.

Palloff, R. M., \& Pratt, K. (2015). Lessons from the Virtual Classroom: The Realities of Online Teaching. Porto Alegre: I Think.

Rahmi, W. M., Othman, M. S., \& Musa, M.A. (2014). The Improvement of Students' Academic Performance by Using Social Media through Collaborative Learning in Malaysian Higher Education. Asian Social Science, 10.

https://doi.org/10.5539/ass.v10n8p210

Roberts, T. S. (2005). Computer-Supported Collaborative Learning in Higher Education: An Introduction. In T. S. Roberts (Ed.), Computer-Supported Collaborative Learning in Higher Education (pp. 1-18). London: Idea Group Inc.

https://doi.org/10.4018/978-1-59140-408-8 
Santos, A. I. dos. (2012). Open Education: History, Practices and the Context of Open Educational Resources. In B. Santana, C. Rossini, \& N. de L. Pretto (Eds.), Open Educational Resources: Collaborative Practices Public Policies. Salvador: Edufba; São Paulo: Houseof Digital Culture.

https://web.archive.org/web/20160304132617/www.livrorea.net.br/livro/livroREA-1edi cao-mai2012.pdf

Santos, A. I. dos (2013). Open Educational Resources in Brazil: The State of the Art, Challenges and Perspectives for Development and Innovation. Translation DB Communication. São Paulo: Internet Steering Committee in Brazil.

http://cetic.br/publicacoes/2012/rea-andreia-inamorato.pdf

Torres, P. L. (2004). Online Learning Laboratory: A Critical Proposal of Collaborative Learning for Education. Tubarão: Unisul Ed.

Torres, P. L. (2007). Some Ways to Interweave Thinking and Acting. Curitiba: SENARPR.

Torres, P. L., Alcântara, P. R., \& Irala, E. A. F. (2004). Consensus Groups: A Proposal of Collaborative Learning for the Teaching-Learning Process. Journal of Educational Dialogue. Curitiba, 4, 129-145.

Veen, W., \& Vrakking, B. (2009). Homo Zappiens: Educating in the Digital Age. Porto Alegre: Artmed.

\section{Submit or recommend next manuscript to SCIRP and we will provide best} service for you:

Accepting pre-submission inquiries through Email, Facebook, LinkedIn, Twitter, etc. A wide selection of journals (inclusive of 9 subjects, more than 200 journals)

Providing 24-hour high-quality service

User-friendly online submission system

Fair and swift peer-review system

Efficient typesetting and proofreading procedure

Display of the result of downloads and visits, as well as the number of cited articles

Maximum dissemination of your research work

Submit your manuscript at: http://papersubmission.scirp.org/

Or contact ce@scirp.org 